IMPRINT

\author{
PUBLISHER AND PUBLISHING HOUSE: \\ Expert Fachmedien GmbH \\ Aachener Str. 172, 40223 Düsseldorf \\ Germany \\ Phone: +49 (0) 211 / 15 91-2 10, Fax: +49 (0) 2 11 / 15 91-1 50 \\ www.expert-fachmedien.de, www.interceram-review.info \\ Management: Paul Robert Hoene \\ Owner of title rights: DVS Media GmbH, Düsseldorf, Germany
}

\section{EDITORIAL DEPARTMENT:}

Dr. Hubert Pelc (managing editor/responsible)

Phone: +49 (0) 211 / 15 91-2 30 // E-Mail: hubert.pelc@dvs-hg.de

Dr.-Ing. Paul-Eberhard Keilbar

Phone: +49 (0) 341 / 9410237 // E-Mail: keilbar@t-online.de

Sylvia Hanagan (editorial assistant)

Phone: +49 (0) 211 / 15 91-2 31 // E-Mail: sylvia.hanagan@dvs-hg.de

EDITORIAL COMMITTEE OF INTERCERAM - INTERNATIONAL CERAMIC REVIEW:

Prof. C.G. Aneziris, Germany, Prof. Dr. A. Boccaccini, Great Britain, Prof. Ph. Boch, France, Prof. Dr. A.O. Boschi, Brazil, Dr. José Carlos Bressiani, Brazil, Prof. D.R. Dinger, USA, Dr. Sc. tech. Jiri Götz, Czech Republic, Prof. Dr. rer. nat. Olaf Krause, Germany, Prof. Dr. W. Krönert, Germany, Dipl.-Ing. (FH) J. Mendheim, Germany, Dr. rer. nat. H. Mörtel, Germany, Dr. R. Muccillo, Brazil, Prof. Dr. V.C. Pandolfelli, Brazil, Eng. J.Q. Peng, P.R. China, Dr. A. Ravaglioli, Italy, Dr. A. J. Ruys, Australia, Prof. Dr. R. Salomão, Brazil, B. Sezer, Turkey, Dr. R. G. Shah, India, Prof. S. Somiya, Japan, Dr. St. Stefanov, Bulgaria, Dr. G. Sukul, India, Dr. A.G. Verduch, Spain, Dr. S. Zhang, Great Britain

LAYOUT:

Julia Bobe, Expert Fachmedien GmbH

PRINTING:

$D+L$ Printpartner GmbH

Schlavenhorst 10, 46395 Bocholt

\section{ADVERTISEMENTS:}

Christiane Czech (responsible)

Phone: +49 (0) 2 11 / 15 91-1 57 // E-Mail: christiane.czech@dvs-hg.de

\section{SUBSCRIPTION:}

Expert Fachmedien GmbH

Alexander Werum

Reader service

Große Hub 10, D-65344 Eltville

Phone: +49 (0) 6123 / 92 38-2 23, Fax: +49 (0) 6123 / 92 38-2 44

E-Mail: interceram@vuservice.de

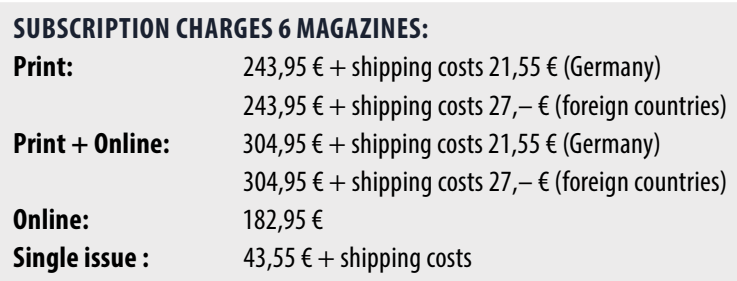

○ Copyright 2017 // Expert Fachmedien GmbH // D-40223 Düsseldorf, Germany

ISSN: 0020-5214

"INTERCERAM - International Ceramic Review" and its special edition "INTERCERAM Refractories Manual" as well as the contributions, figures and tables included in these journals are protected by copyright. With the exception of the statutorily authorised cases, any utilisation without the consent of Expert Fachmedien $\mathrm{GmbH}$ is punishable. We do not accept any liability for manuscripts submitted without solicitation. When the work is accepted for publication, the author transfers to the publishing house the exclusive publishing rights for the period until the copyright expires. This transfer of rights relates, in particular, to the rights of the publishing house to reproduce the work for commercial purposes as a copy (microfilm, photocopy, CD-ROM or other processes) and/or to include it in electronic or other databases.

\section{Please turn over!}

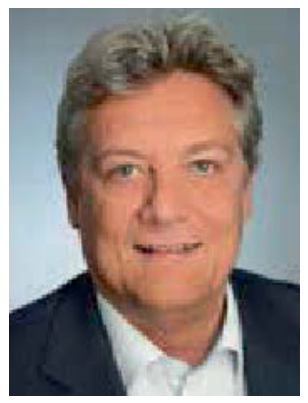

Dear Readers,

You are sure to have immediately noticed that INTERCERAM is now presented in a new format, i.e. in combination with KERAMISCHE ZEITSCHRIFT. You are now holding the premiere joint issue of our journals.

However, this does not mean that the two publications have been merged; they will continue as independent editions with separate contents, including their own covers. We designed alternative packaging, in which the journals are linked together through a combined bilingual suppliers' index that now features each company's logo.

Readers and subscribers of INTERCERAM will have the advantage of gaining insight into German scientific papers via their English language abstracts in KERAMISCHE ZEITSCHRIFT. If desired, you will also be able to contact the authors - for further data or potential research collaboration. This means more information - but no change in price.

Furthermore, visibility of advertisements and/or company and product information will be significantly increased, as distribution of the two titles will be extended to both the German-speaking world and the international market. Despite the somewhat more elaborate typesetting and printing process required for the alternative format, our advertising prices will remain at the same level as last year.

Planning and preparations for participating in ceramitec 2018 have begun in many businesses. The industry is currently reinventing itself. From 10 to 13 April 2018, ceramitec will also be innovative and lead the way to new application possibilities, not just in ceramics.

My tip: If you register as an exhibitor by 31 March 2017 at www.ceramitec.com, you will receive free vouchers for all-day tickets to give to your customers.

As official media partner of ceramitec, we will of course gladly be at your service. Let us know about your participation in the trade fair or if you would like to advertise your products in advance.

Don't hesitate to talk to us!

Hubert Pelc

redaktion-keramik@dvs-hg.de 